\title{
Effectiveness of Tutoring to Improve Academic Performance in Nursing Students at the University of Seville
}

\author{
María Dolores Guerra-Martín¹, Marta Lima-Serrano®i), Joaquín Salvador \\ Lima-Rodríguez ${ }^{3}$ \\ ${ }^{1}$ Department of Nursing, School of Nursing, Physiotherapy and Podiatry, University of Seville \{guema@us.es\} \\ 2Department of Nursing, School of Nursing, Physiotherapy and Podiatry, University of Seville \{mlima@us.es\} \\ 3Department of Nursing, School of Nursing, Physioteraphy and Podiatry, University of Seville \{joaquinlima@us.es\} \\ Received on 19 July 2016; revised on 10 October 2016; accepted on 14 November 2017; published on 15 July 2017
}

DOI: 10.7821/naer.2017.7.201

(c) BY-NC-ND

\begin{abstract}
In response to the increase of Higher Education support provided to tutoring programs, this paper presents the design, implementation and evaluation of a tutoring program to improve the academic performance of at-risk students enrolled in the last year of a nursing degree characterized by academic failure (failed courses). A controlled experimental study was carried out to evaluate a tutoring program that included a minimum of nine meetings performed by an expert professor as tutor. A questionnaire for assessing the academic needs was designed and interventions were performed when responses were: nothing, a little or something. Medium to large effects were found in the progress of failed course to passed course $(p=.000, r \varphi=.30)$, improving the information about courses $(p<.001, d=2.01)$, the information comprehension $(p<.001, d$ $=0.85)$ and the strategies to improve academic performance $(p<$ $.001, d=1.37$ ). The intervention group students' response highlighted program satisfaction and effectiveness. The significance of the study lies in reinforcing the formal tutoring as a tool to improve academic performance in at-risk students.
\end{abstract}

KEYWORDS: UNIVERSITY CURRICULUM, CURRICULUM RESEARCH, LEARNING, TUTORING, ACADEMIC ACHIEVEMENT

\section{JUSTIFICATION}

In Higher Education, academic failure defined as not passing subjects, reaches high proportions. In 2012 the net rate of graduation in the European Union was $37.9 \%$, and in that same year the net rate of graduation in Spain stood at $29 \%$, below the average of the European Union (Ministry of Education, Culture and Sports, 2015; Ministry of Education and Science, 2014). This low productivity is characterized by high attrition and academic delay in the completion of each study. Only $26 \%$ of students completed their studies within the time limits (Fernández, Arco, López, \& Heilborn, 2011). Specifically, in nursing studies, academic failure and attrition is a major problem worldwide (Peterson, Bryer, \& Nikolaidou, 2013; Pryjmachuk, Easton, \& Littlewood, 2009). So,

*To whom correspondence should be addressed:

Department of Nursing, School of Nursing, Physiotherapy and Podiatry, University of Seville. C/ Avenzóar, $n^{\circ} 6$.

Sevilla-41009. it is widely accepted that nursing students need support and guidance (Glossop, 2002; Urwin et al., 2010).

In response to this situation, tutoring is proposed as a strategy to increase student retention, progression and completion (Arbizu, Lobato, \& del Castillo, 2005; Braine \& Parnell, 2011; Cooke, Barkham, Audin, Bradley, \& Davy, 2004; Crisp \& Cruz, 2009; Dorsey \& Baker, 2004; Fowler \& Norrie, 2009; Guerra-Martín, 2015). According to Miller (2002), tutoring could be understood as being different to mentoring, given that the focus of tutoring was on subject learning whereas the focus of mentoring was on life learning that includes a psychological and emotional approach. Following other authors, tutoring should include learning orientation or help and support for students and can be defined as a formative activity which affects the integral development of college students and includes an intellectual, academic, professional and personal approach (Guerra-Martín, 2014; 2015; Perandones \& Lledó, 2009).

Although the majority of quantitative studies regarding tutoring were based on non-experimental methods, quantitative researchers have begun to move beyond descriptive investigations, towards an understanding of the causal relationship between tutoring and student success (Crisp \& Cruz, 2009). Carrying out longitudinal studies is recommended to test the predictive validity of tutoring (Paglis, Green, \& Bauer, 2006), under control for extraneous variables by using control groups (Meinel et al., 2011).

In 2010 a tutoring program was funded by the University of Seville (Spain) with the objectives of reducing academic failure and facilitating the completion for at-risk students characterized by low academic performance, i.e., failed subjects. Following Salinitri (2005) these could be low-achieving students, who are are a particular challenge because they may have uncovered several academic needs related to information about the subjects, comprehension of information, and poor academic strategies, such as poor study habits or the students do not seek or know how to seek help.

\section{STATE OF AFFAIRS}

\subsection{Academic failure}

Different studies have been performed to identify the reasons that explain the students' failure and attrition (Braine \& Parnell, 
2011; Cooke et al., 2004; DeLapp, Hautman, \& Anderson, 2008; Fowler \& Norrie, 2009; Peterson, Bryer, \& Nikolaidou, 2013). On the other hand, Wild and Ebbers (2002) have identified student completion rates as a fundamental measurement of institutional success in meeting student needs. Tutoring can be a strategy to prevent academic failure. Tutoring should include activities designed to improve students' academic performance and successfully complete their studies (Crosier et al., 2012; Dobinson, 2006; Guerra-Martín, 2015; Rhodos \& Jinks, 2005; Watts, 2011).

\subsection{Tutoring programs help student success}

In recent years, there has been increased interest in studying the literature on the impact of tutoring different types of students including minorities, first-year university students, or and low-achieving students (Crisp \& Cruz, 2009). According to these authors, one of the most methodologically rigorous studies was conducted by Campbell and Campbell (1997). They used an experimental design to determine the effect of tutoring intervention on academic success of first-year students attending a metropolitan university. They used faculty members (administrators and staff) as tutors; and found that after the intervention tutored students had significantly higher grade point averages (GPA) than non-tutored students.

Jeffreys (2001) evaluated the impact of a peer-tutoring program on at risk nursing students regarding academic and psychological outcomes. Tutors were students enrolled in upper-levels of nursing programs. Descriptively, they found that study group participants achieved higher pass rates, lower dropout rates, and positive satisfaction with the program.

Salinitri (2005) evaluated a tutoring program based on social learning and social capital theories, by means of examining the retention rate (number of passed subjects) and program satisfaction of first-year university students. They used intermediate/senior teacher candidates previously trained as tutors. The retention rates and CPA of the experimental group were higher than those for the control group. The results reflected program satisfaction and students noted its effectiveness in written comments.

Phinney, Torres, Padilla and Kim (2011), showed the process and effect evaluation of a tutoring program for Latino first-year college students on academic and psychosocial characteristics. This was based on attachment, sociocultural, and peer-tutoring theories. They used graduate and senior students as tutors; and although they found effects on psychosocial variables, there was a lack of effect on GPA that was explained by the non-use of structured interactions.

In Spain, Alonso, Castaño and Calles (2010) carried out a study to evaluate the impact of a peer-tutoring program, where older fifth-year students took on the role of mentors of fourth-year students; they found improvements in knowledge about the academic setting as a consequence of the program and the mentors achieved a better average grade but no statistically significant effects were found on psychological variables. Arco-Tirado, Fernández-Martín and Fernández-Balboa (2011) also determined the impact of a peer-tutoring program, where older and more experienced and previously trained students (seniors, Masters students) acted as tutors. The program was not effective on GPA but had some benefits on learning strategies and the social skills of mentees. Finally, Hryciw, Tangalakis, Supple and Best (2013) evaluated the effectiveness of a peer-assisted study session program for a large class of Bachelor of Health Science (Paramedic) students. Specifically they assessed first-year undergraduate student perceptions of the program and they found that $63 \%$ indicated that they had a better understanding of the subject, with $40 \%$ of mentees specifi- cally saying that their knowledge had increased; $52 \%$ of mentees indicated that completing the program gave them confidence in working in a group setting.

\subsection{Background: concept of tutoring and the design of tutoring programs}

Tutoring is a formal process that involves as a relationship between a more experienced and knowledgeable person that plays a supportive role with a less experienced and knowledgeable person, so as to facilitate that person's career and personal development (Crisp \& Cruz, 2009; Dorsey \& Baker, 2004; Guerra-Martín, 2015). Tutoring involves several attributes, such as coaching, assessing, facilitating, sponsoring, supporting, guiding, role modeling (Crisp \& Cruz, 2009; Guerra-Martín, 2015), while also involving some interpersonal dynamics such as support, trust, a personal connection, career development, and student empowerment (Arbizu et al., 2005; Guerra-Martín, 2014; Hauer, Teherani, Dechet, \& Agaard, 2005; Scott, 2005).

In an attempt to classify the different theoretical frameworks that guide the tutoring, Jones and Brown (2011) distinguished three different models, i.e., the traditional model, the reciprocal model, and the emergent model. The traditional model is based on a hierarchical relationship between a tutor and a protégé in which the first transmits knowledge, information, or support to the protégé. This kind of relationship could have several benefits for the protégé such as psychosocial or career-outcome (Crisp \& Cruz, 2009; Dorsey \& Baker, 2004; Jones \& Brown, 2011). The reciprocal model emphasizes the collaborative nature of the tutoring relationship, in this case both tutor and protégé could benefit, and an emotional connection could be created. Finally, although traditional and reciprocal models are the most commonly mentioned in literature, new conceptualizations have emerged such as reverse model, peer tutoring, or the complex adaptive systems that include the role of the university institution or the socio-cultural environment (Jones \& Brown, 2011).

Crisp and Cruz (2009) proposed a theoretical framework with four latent constructs of tutoring that include psychological and emotional support, support for setting goals and choosing a career path, academic knowledge support, and specification of a role model.

In the present work, given our main objective of improving the academic performance of students that failed previous subjects, we considered that the traditional model could be the most appropriate to guide the tutoring program. Given that we have focused on academic tutoring as a strategy to facilitate the success of university students (Arbizu et al., 2005; Dorsey \& Baker, 2004; Guerra-Martín, 2015; Miller, 2002).

In this respect, in recent years we found different studies, which focus on the designing of tutoring programs. According to the research, a tutoring program should be previously planned and should be adapted to the context and to the needs and interests of the students. In a tutoring program, the tutors should be a fu11-time professor that gives advice and orientation individually or in small-groups of students, through personalized attention, with the objective of encouraging good studying habits. Tutoring programs with these characteristics could improve the academic performance of college students and, therefore, reduce the academic failure, attrition and academic delay in the completion of their studies (Gómez-Collado, 2012; Guerra-Martín, Lima-Serrano, \& Lima-Rodríguez, 2016; Hernández, Martínez, \& Carranza, 2013; Lemus, Torres, Serrano, \& Gúzman, 2015; Velázquez-Sagahón \& Rodríguez de la Osa, 2014). 


\subsection{Contextualization and definition of the research problem}

The University of Seville had around 500 undergraduate nursing students, three out of four were women, and the average age was 21 years old. At the Department of Nursing, which teaches most of the subjects of the nursing degree, there were around 100 professors, most of them with a bachelor in nursing, around $40 \%$ of them had taught for more than 10 years and the same percentage were full-time professors. Regarding educational strategies in the Nursing Degree, $60 \%$ percent of the learning was mainly through lectures to large-groups (roughly 60 students), and the rest were theoretical-practical seminaries in small-groups. In the evaluation, both learning scenarios were considered. On the one hand, the students had to pass an exam, in which knowledge acquisition is assessed by means of open or closed questions. On the other hand, the professors evaluated the acquisition of skills in the theoretical-practical seminaries by demonstrations or simulations.

In 2009-2010, 194 students were enrolled in the final year of nursing, 129 were women (74\%) and the mean age was 22.6 years old $(\mathrm{SD}=3.02)$. Of the aforementioned, $104(53.6 \%)$ had failed subjects in previous years with a total of 175 failed subjects (mean $=5, \mathrm{SD}=1.89$ ). Therefore, we considered them students atrisk of academic failure.

Faced with this problem, a group of professors designed and developed a tutoring program to enhance the academic performance of these students. It was intended for the professor to give support to the tutor figure, and to delve into the urgent need for greater theoretical and empirical research in the concept, the practice and experiences in personal tutoring of students in higher education (Crisp \& Cruz, 2009; Watts, 2011).

The aim of this study was to evaluate the effect of the tutoring program on the academic performance. This overall aim can be broken down into:

- Design and implement a tutoring program to improve the academic performance in at-risk nursing students form the last year of nursing at the University of Seville.

- Evaluate the effect of the tutoring program on the progress from the failed subject to passed subject.
- Evaluate the effect of the tutoring program on the improvement regarding the information about the subjects, the understanding of said information, and the strategies used for improving their performance.

- Understanding student response and program satisfaction with the tutoring program.

The main hypothesis of this study is that those students in the last year of nursing that participate in the tutoring program will have better academic performance at the end of the year, i.e., they will progress more from the failed subject to passed subject, versus those students that only participate in the usual tutoring with the subject professors.

The second hypothesis is that those who participate in the tutoring program will gain more information about the subjects, more understanding of said information, and more strategies for improving their performance, versus those students that only participate in the usual tutoring with the subject professors.

\section{METHODOLOGY}

\subsection{Design}

An experimental design pre-posttest was chosen with measurements in an experimental group (EG) and in a control group (CG).

\subsection{Participants and sample}

The sample size calculation was calculated for the variable academic performance (failed subjects) by using G*Power 3 given an $\alpha=.05$, power $(1-\beta)$ of $80 \%$, and large effect size ( $\mathrm{r} \phi=$ 0.5 ). The sample should be 32 students, divided into EG and CG. However, by a randomized type of sample, using a random number generator, we selected 44 students from the class list that were invited by e-mail. Subsequently, they were randomly assigned to each group taking in account the number of failed subjects for matching. When starting the study 22 participants in the EG had 87 failed subjects and 22 participants in the CG had 88 failed subjects. Students not were informed of the condition to which they had been assigned (Figure 1).

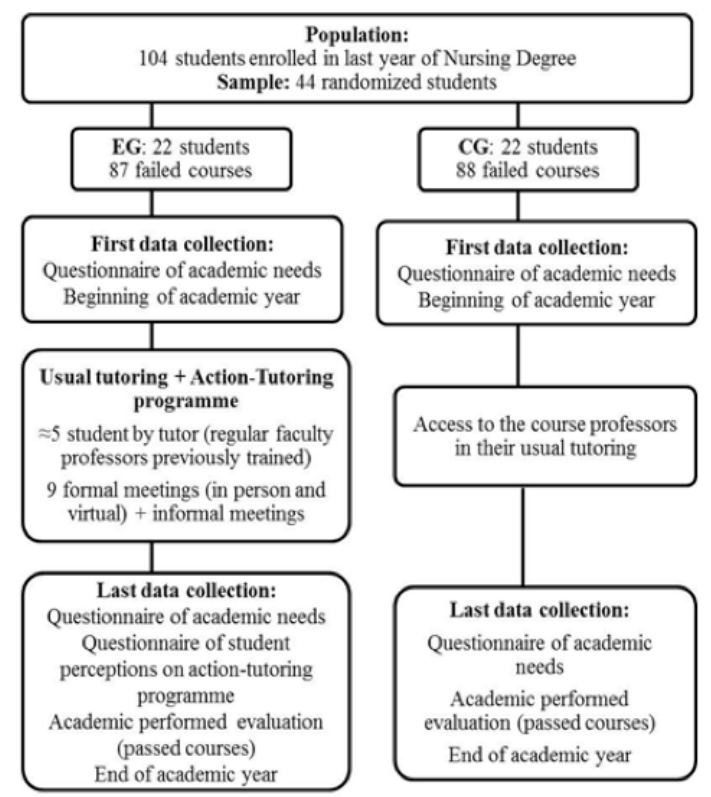

Figure 1. Participant flow chart 


\subsection{Intervention}

Five regular faculty professors, who taught in the last year, voluntarily collaborated with the funding project and participated as tutors. They were required to have more than five years of teaching experience.

A questionnaire for assessment of academic needs was designed which was based on that proposed by Valverde, García and Romero (2003), and another to assess student perceptions on the tutoring program. The first consisting of 19 items with a Likert scale (1: nothing, 2: little, 3: something, 4: quite a lot, and 5: everything). The second consisted of 15 items, divided into three categories: 1 . Tutoring suitability, 2 . Tutoring timing, and 3. Improvements perceived by students, with a Likert scale (1: no agreement to 5: full agreement); and an open section where students could provide feedback was included. The latter questionnaire was applied to students in the EG.

The questionnaire for assessment of academic needs was previously validated by triangulation with 20 professors in two successive rounds of feedback and suggestions (Lima-Rodríguez, Lima-Serrano, Jiménez-Picon, \& Domínguez-Sánchez, 2013), and its psychometric properties were tested by using an exploratory factor analysis and analysis of the internal consistency by Cronbach's alpha test. Three subscales were formed: Scale information, to measure the acquisition of information about the subject, with seven items (1-7) $(\alpha=0.81$ at pretest and $\alpha=0.87$ at posttest); the Scale comprehension, to measure understanding of the information on the subject and other skills, with five items (8-12) $(\alpha=0.85$ at pretest and $\alpha=0.81$ at posttest); the Scale strategy, to measure those strategies used for the improvement of academic performance in the subject, with seven items (13-19) ( $\alpha$ $=0.78$ at pretest and $\alpha=0.87$ at posttest).

Regarding the intervention plan, while both EG and CG could access the subject professors in their usual tutoring, EG was also included in a specific tutoring program.

\subsection{Tutoring Program}

Each tutor tutored a maximum five students who were randomly assigned.

The program coordinator had continuous meetings with the Department of Education at the University of Seville in order to improve her knowledge and skills about theory and practices of tutoring, advising and assisting students. In addition, she was provided with material resources related to study techniques. Subsequently, ten two-hour meetings were established between the program coordinator team and tutors to plan and handle the work plan before and during the development of the tutoring program. Of these, four were performed prior to starting the intervention, in which she gave information about knowledge, skills and resources as well as showing the study objectives, the characteristics of the tutoring program, and the assessment tools were reported and discussed. The rest of the meetings were aimed at the follow-up program implementation and evaluation.

We used a one-to-one academic and traditional tutoring model, in which the expert professor supported the student by acting as an assessor, a guide, a coach, and a feedback provider in order to develop academic and emotional strategies to achieve academic success. The tutoring program lasted the whole academic year (from September 2009 to July 2010). The tutoring could be formal and informal, i.e., outside the time and place allocated for formal tutoring. A minimum of nine formal meetings, four "in person" (around an hour in length) and four virtual (email, phone, etc.), were given to each student of EG. However, every student could contact their tutor whenever they needed to, so continuous personal contact was provided. Tutoring interventions were carried out only on those issues from the questionnaire for assessment of academic needs in which students had responded: nothing, little or something.

The following actions were taken during formal meetings: The first meeting was carried out "in person" at the beginning of the academic year. This covered the following tasks: an interview to know the personal circumstances of students, complementing the questionnaire for assessment of academic needs, proposal of recommendations to improve academic performance based on identified needs, and agreement on a work-plan according to the needs identified. In addition, reading the subject syllabus was proposed to all students, given the importance of the information that it collects to help to prepare the subject and to develop the exams. In those students that had more than three failed subjects it was necessary to conduct the meeting in two one-hour sessions.

The second meeting was carried out in a virtual meeting between two weeks and one month after the first in order to follow-up the work-plan, and the majority of questions approached were designed to know if the student had read and understood the syllabus of the failed subject, to understand if student had had contact with the subject professor, if they had attended any class or tutoring with the professor of the subject, and other academic issues such as information management and study techniques, among other things.

Subsequently, another three "in person" meetings were carried out before December, February and June tests, respectively. Special attention was given to those subjects when the student had decided to take exam on those dates. In addition this covered the following tasks: assessment of compliance with previously established work-plan according to identified needs, addressing the weaknesses and possible solutions, reinforcement of positive attitudes towards the study, and modification, if necessary, the work-plan until the following meeting.

On the other hand, another three "virtual" meetings were carried out after receiving December, February and June marks, respectively. In this tutors gave follow-up, feedback, and support, and encouraged the students to follow the work-plan.

The last meeting was performed in order to complete the questionnaire for assessment of academic needs (posttest) and the questionnaires to assess student perceptions on the tutoring program.

Informed consent was requested and permission from the Experimentation Ethics Committee of the University of Seville, which comply with the regulations in force in Spain and the European Union.

\subsection{Evaluation of the effectiveness of the tutoring program}

The data obtained was analyzed by SPSS version 21.0 (Field \& Babbie, 2011). Regarding previous studies (Salinitri, 2005), the main outcome identified was the students' academic performance that was calculated, using a qualitative variable (yes/no), which measured progress from the failed subject to passed subject, according to data provided by the secretariat of the Faculty. By using a $2 \times 2$ table the Pearson chi-square test $\left(\mathrm{X}^{2}\right)$ was calculated. The effect size was measured by the contingency coefficient ( $\mathrm{r} \varphi$, low $=.1$, medium $=.3$ and high $=.5$ ).

To evaluate the effect on the different scales new variables were constructed, namely progress on the Scale of Information, the Scale of Comprehension, and the Scale of Strategy. An hypothesis test was performed using the Mann-Whitney U statistic, 
rejecting the null hypothesis with p-values $<.05$. Cohen's d (low $=.1$, medium $=.3$ and high $=.8$ ), in order to evaluate the effect size was used. As we found compositional differences between the two groups in terms of gender, we carried out a stratified analysis by this variable. This analysis has counteracted different compositions in EG and CG and, therefore, reduced the deviation and increased the validity.

A descriptive analysis was performed of the closed answers given by EG students to the questionnaire of perceptions on the tutoring program. Regarding answers to open questions, two members of the research team carried out a content analysis using the Atlas.ti version 6.3 (Pope, Ziebland, \& Mays, 2000).

\section{RESULTS}

The average age in the EG was $22.1(\mathrm{SD}=.63)$ and in the $\mathrm{CG} 22.7$ $(\mathrm{SD}=.72)$ years; no differences were found in both groups $(\mathrm{Z}=$ $-.62, \mathrm{p}=.535)$. The EG had 13 women and 9 men, and the $\mathrm{CG}$ with 19 women and 3 men, and there was a statistically significant difference $(\mathrm{X} 2[1,44]=27.01, \mathrm{p}=.000)$.

\subsection{Academic Performance (progress from the failed subject to passed subject)}

At the end of the study, the EG had passed 60 subjects and the CG had passed 33 subjects. There was a statistically significant difference in favor of EG in the progress of failed subject to a passed subject $\left(\mathrm{X}^{2}[1,175]=17.40, \mathrm{p}=.000, \mathrm{r} \varphi=.30\right)$.
Effect on the variables collected in the questionnaire for assessment of needs (information, comprehension and strategies) Large statistically significant effect sizes of the tutoring program were obtained on the progress of the scores in the information scale, in the comprehension scale, and in the strategy scale,being higher on the information scale. As differences were found between groups in terms of gender, we decided to differentiate the results based on this variable. The effect was greater in women for progress in the information scale, while it was higher in men for progress in the strategy scale. Moreover, progress in the comprehension scale was not statistically significant in men (Table 1 ).

Figures 2-4 show the change in mean scores on these scales from pretest to posttest, i.e., before and after the implementation of the tutoring program both by conditions and by gender.

In addition, looking at the mean scores and standard deviations for each item of the questionnaire on pretest and posttest, the mean score increased and standard deviation (that is the variability in the scores) decreased in all questionnaire items in the EG while the increase in mean scores was lower in the CG and after the intervention there was still a great variability regarding standard deviation (Table 2). The item that received the highest average score in EG in posttest was "I have read the subject syllabus", and that the greatest increases were "I have attended subject tutoring to clarify information and doubts" and "It is easy for me to handle databases", on the other hand, items that experienced a smaller increase in this group were "I have attended classes on the subject regularly", "I understand the professor's explanations", and "I find it easy to apply the knowledge to solve a problem or case study".

Table 1. Progression (from the pretest to posttest) in the different scales on information, comprehension and the strategies to improve the performance in subjects

\begin{tabular}{|c|c|c|c|c|c|c|c|c|c|}
\hline Variable & $\begin{array}{l}\text { Segment } \\
\text { analyzed }\end{array}$ & Group & $\mathbf{N}^{*}$ & $\begin{array}{l}\text { Mean } \\
\text { ranks }\end{array}$ & $\begin{array}{l}\text { Sum of } \\
\text { ranks }\end{array}$ & U Mann-Whitney & $\mathbf{Z}$ & $\mathbf{P}$ & d \\
\hline \multirow{6}{*}{$\begin{array}{l}\text { Progress in Scale } \\
\text { information }\end{array}$} & \multirow[t]{2}{*}{ Complete sample } & EG & 87 & 12.41 & 11084.50 & \multirow[t]{2}{*}{399.50} & \multirow[t]{2}{*}{-10.37} & \multirow[t]{2}{*}{.000} & \multirow[t]{2}{*}{2.01} \\
\hline & & $\mathrm{CG}$ & 88 & 49.04 & 4315.50 & & & & \\
\hline & \multirow[t]{2}{*}{ Women } & EG & 49 & 101.40 & 4968.50 & \multirow[t]{2}{*}{176.50} & \multirow[t]{2}{*}{-8.83} & \multirow[t]{2}{*}{.000} & \multirow[t]{2}{*}{2.08} \\
\hline & & $\mathrm{CG}$ & 80 & 42.71 & 3416.50 & & & & \\
\hline & \multirow[t]{2}{*}{ Men } & EG & 38 & 20.20 & 995.50 & \multirow[t]{2}{*}{49.50} & \multirow[t]{2}{*}{-2.99} & \multirow[t]{2}{*}{.002} & \multirow[t]{2}{*}{1.41} \\
\hline & & $\mathrm{CG}$ & 8 & 10.69 & 85.50 & & & & \\
\hline \multirow{6}{*}{$\begin{array}{l}\text { Progress in Scale } \\
\text { comprehension }\end{array}$} & \multirow[t]{2}{*}{ Complete sample } & EG & 87 & 108.74 & 9460.00 & \multirow[t]{2}{*}{2024.00} & \multirow[t]{2}{*}{-5.94} & \multirow[t]{2}{*}{.000} & \multirow[t]{2}{*}{.85} \\
\hline & & CG & 88 & 67.50 & 5940.00 & & & & \\
\hline & \multirow[t]{2}{*}{ Women } & EG & 49 & 88.71 & 4347.00 & \multirow[t]{2}{*}{798.00} & \multirow[t]{2}{*}{-6.37} & \multirow[t]{2}{*}{.000} & \multirow[t]{2}{*}{1.05} \\
\hline & & $\mathrm{CG}$ & 80 & 50.48 & 4038.00 & & & & \\
\hline & \multirow[t]{2}{*}{ Men } & EG & 38 & 23.79 & 904.00 & \multirow[t]{2}{*}{141.00} & \multirow[t]{2}{*}{-.34} & \multirow[t]{2}{*}{.369} & \multirow[t]{2}{*}{.12} \\
\hline & & $\mathrm{CG}$ & 8 & 22.13 & 177.00 & & & & \\
\hline \multirow{6}{*}{$\begin{array}{l}\text { Progress in Scale } \\
\text { strategy }\end{array}$} & \multirow[t]{2}{*}{ Complete sample } & EG & 87 & 103.96 & 9044.50 & \multirow[t]{2}{*}{2439.50} & -4.15 & .000 & 1.37 \\
\hline & & $\mathrm{CG}$ & 88 & 72.22 & 6355.50 & & & & \\
\hline & Women & EG & 49 & 76.57 & 3752.00 & 1393.00 & -2.75 & .003 & .61 \\
\hline & & $\mathrm{CG}$ & 80 & 57.91 & 4633.00 & & & & \\
\hline & Men & EG & 38 & 25.04 & 951.50 & 93.50 & -1.70 & .045 & .83 \\
\hline & & $\mathrm{CG}$ & 8 & 15.19 & 129.50 & & & & \\
\hline
\end{tabular}

Note: Refers to the number of failed subjects by the participants. 


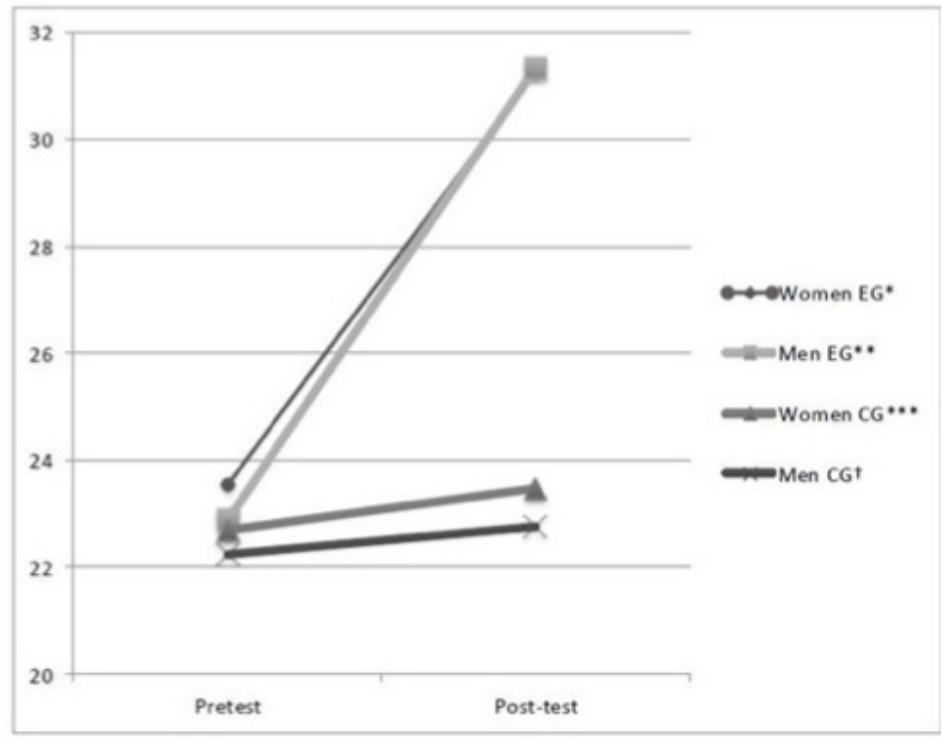

"EG women, pretest: $23.55 \pm 4.37$ (minimum $=8$, maximum $=30$ ) and post-test: $31.27 \pm 2.40$ (minimunr -22 , maximum $=35$ )

**EG men, pretest: $22.90 \pm 4.72$ (minimum $=13$, maximum $=30$ ) and post-test: $31.34 \pm 2.62$ (minimum $=20$, maximum $=35$ )

***CG women. pretest: $22.68 \pm 5.69$ (minimum $=11$, maximum $=33$ ) and posttest: $23.48 \pm 5.70$ (minimum-12, maximum-34)

†CG men, pretest: $23.48 \pm 5.70$ (minimum=12, maximum $=34$ ) and post-test:

$24.75 \pm 2.31$, minimum $=22$, maximum $=28$ )

Figure 2. Progress from pretest to posttest in the mean score of the Scale information in regard to sex and condition

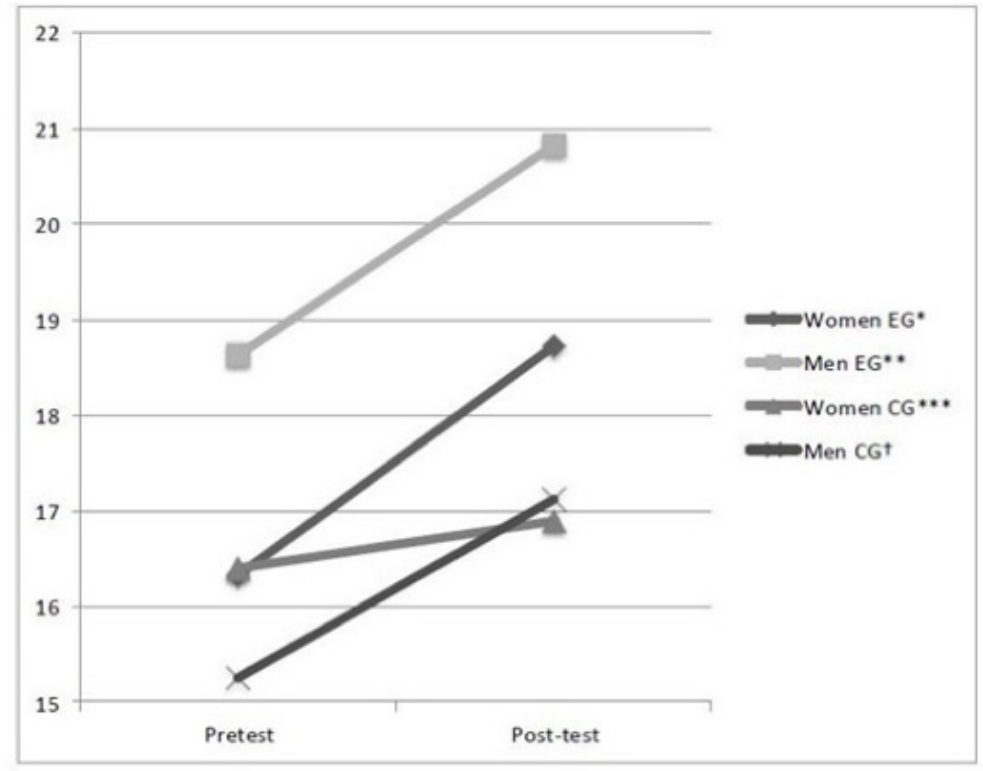

*EG women, pretest: $16.33 \pm 2.63$ (minimum=10, maximumF 22 ) and posttest: $18.73 \pm 2.33$ (minimum $=13$, maximum $=23$ )

**EG men, pretest: $18.63 \pm 4.00$ (minimum $=7$, maximum $=25$ ) and post-test: $20.82 \pm 3.34$ (minimum $=7$, maximum $=25$ )

*** CG women, pretest: $16.40 \pm 3.46$ (minimum=7, maximum=22) and posttest: $16.90 \pm 3.53$ (minimum $=7$, maximum $=22$ )

$\doteqdot C G$ men, pretest: $15.25 \pm 1.70$ (minimum $=12$, maximum $=17$ ) and post-test: $17.12 \pm 2.64$, minimum $=12$, maximum $=20$ )

Figure 3. Progress from pretest to post-test in the mean score of the Scale comprehension in regard to sex and condition 


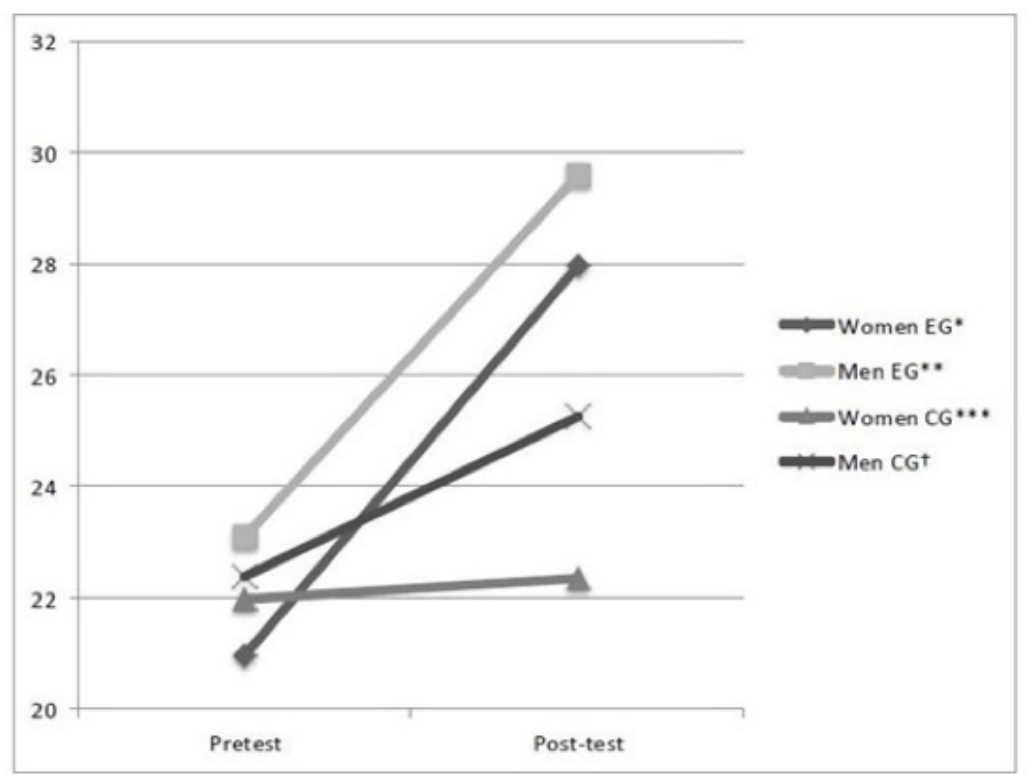

"EG women, pretest: $20.96 \pm 3.22$ (minimum $=16$, maximum $=28)$ and posttest: $27.98 \pm 3.54(\operatorname{minimum}=22$, maximum $=33)$

**EG men, pretest: $23.08 \pm 5.10($ minimum $=12$, maximum $=31)$ and post-test: $29.61 \pm 3.33$ (minimum $=21$, maximum $=35$ )

***CG women, pretest: $21.96 \pm 4.62$ (minimum $=11$, maximum $=31$ ) and posttest: $22.36 \pm 4.81$ (minimum $=11$, maximum $=31$ )

†CG men, pretest: $22.38 \pm 3.42$ (minimum $=18$, maximum $=26$ ) and post-test:

$25.25 \pm 2.25$, minimum $=20$, maximum $=27$ )

Figure 4. Progress from pretest to posttest in the mean score for the Scale strategy regarding sex and condition

Table 2. Differences in the mean scores and standard deviations obtained for each of the items of the questionnaire between pretest and posttest, and between both experimental conditions

\begin{tabular}{|c|c|c|c|c|}
\hline & & & \\
\hline & & & $\begin{array}{l}\text { Initial Evaluation } \\
\text { (pretest) }\end{array}$ & $\begin{array}{l}\text { Final Evaluation } \\
\text { (posttest) }\end{array}$ \\
\hline & EG Mean \pm SD & CG Mean \pm SD & EG Mean \pm SD & CG Men \pm SD \\
\hline 1. I have read the subject syllabus & $3.52 \pm .87$ & $3.28 \pm .99$ & $4.86 \pm .35$ & $3.60 \pm 1.05$ \\
\hline 2. I have understood the subject syllabus & $3.54 \pm .90$ & $3.39 \pm 1.25$ & $4.68 \pm .50$ & $3.60 \pm 1.16$ \\
\hline 3. I have attended the class on the subject regularly & $3.24 \pm 1.11$ & $3.20 \pm 1.16$ & $3.47 \pm 1.08$ & $3.24 \pm 1.28$ \\
\hline $\begin{array}{l}\text { 4. I have attended the subject professor tutoring on the subject } \\
\text { for information and doubts }\end{array}$ & $2.08 \pm 1.19$ & $1.91 \pm 1.07$ & $4.53 \pm 0.63$ & $1.97 \pm 1.06$ \\
\hline 5. I am clear about the activities undertaken in the subject & $3.61 \pm .87$ & $3.55 \pm 1.01$ & $4.57 \pm .52$ & $3.64 \pm 1.02$ \\
\hline 6. I am clear about what material I have to use & $3.70 \pm 1.00$ & $3.72 \pm 1.03$ & $4.56 \pm .50$ & $3.83 \pm 1.04$ \\
\hline 7. The evaluation criteria is clear & $3.57 \pm 1.00$ & $3.59 \pm 1.15$ & $4.62 \pm .51$ & $3.72 \pm 1.10$ \\
\hline 8. I understand the professor's explanations & $3.67 \pm .93$ & $3.33 \pm 1.09$ & $3.98 \pm .85$ & $3.50 \pm 1.09$ \\
\hline 9. I understand the subject contents & $3.77 \pm .87$ & $3.66 \pm .76$ & $4.28 \pm .68$ & $3.75 \pm .78$ \\
\hline 10. It is easy for me to memorize the content of the subject & $3.22 \pm .95$ & $3.02 \pm .84$ & $3.70 \pm .70$ & $3.19 \pm .83$ \\
\hline $\begin{array}{l}\text { 11. I find it easy to apply the knowledge to solve a problem or } \\
\text { case study }\end{array}$ & $3.30 \pm .88$ & $3.11 \pm .73$ & $3.83 \pm .70$ & $3.22 \pm .75$ \\
\hline $\begin{array}{l}\text { 12. I find it easy to generate new knowledge based on that } \\
\text { already acquired }\end{array}$ & $3.38 \pm .78$ & $3.17 \pm .73$ & $3.86 \pm .73$ & $3.26 \pm .77$ \\
\hline 13. It is easy for me to handle databases & $2.71 \pm 1.15$ & $2.78 \pm .84$ & $4.11 \pm .83$ & $3.02 \pm .88$ \\
\hline 14. It is easy for me to search for information in the library & $3.45 \pm .82$ & $3.60 \pm .78$ & $4.37 \pm .70$ & $3.62 \pm .76$ \\
\hline 15. I plan my study time & $3.18 \pm .96$ & $2.83 \pm .94$ & $4.45 \pm .57$ & $2.94 \pm .96$ \\
\hline 16. I spend enough time on studying & $3.01 \pm .83$ & $3.07 \pm 1.00$ & $4.37 \pm .61$ & $3.09 \pm 098$ \\
\hline 17. Multiple choice tests are easy to me & $2.67 \pm 1.02$ & $3.24 \pm 1.02$ & $3.47 \pm .79$ & $3.35 \pm 1.03$ \\
\hline 18. It is easy to respond to development questions & $3.26 \pm .95$ & $3.07 \pm .99$ & $3.89 \pm .77$ & $3.12 \pm .99$ \\
\hline 19. Writing the course works is easy for me & $3.54 \pm .83$ & $3.41 \pm 1.06$ & $4.03 \pm .67$ & $3.47 \pm 1.07$ \\
\hline
\end{tabular}




\subsection{Results of assessment of student's perceptions on the tutoring program}

The response of students in the EG to tutoring was very positive, with respect to their suitability, timing, and program effectiveness, i.e., perceived improvements. These are all items rated above four, highlighting those related to the suitability of the tutoring program, although the items "I found the information received before starting the tutoring adequate" and "I have learned study skills" obtained some negative assessment (Table 3).

Table 3. Responses to the questionnaire of assessment student's perceptions on the action-tutoring strategy. Descriptive statistics

\begin{tabular}{|c|c|c|c|c|}
\hline Item & Minimum & Maximum & Mean & SD \\
\hline \multicolumn{5}{|c|}{ Suitability of the action-tutoring strategy } \\
\hline $\begin{array}{l}\text { 1. I found the information } \\
\text { received before starting } \\
\text { the tutoring adequate }\end{array}$ & 2 & 5 & 4.27 & .83 \\
\hline $\begin{array}{l}\text { 2. Tutoring content is } \\
\text { adapted to my needs }\end{array}$ & 4 & 5 & 4.55 & .51 \\
\hline $\begin{array}{l}\text { 3. I consider the tutor has } \\
\text { made a great effort to } \\
\text { help me }\end{array}$ & 4 & 5 & 4.82 & .40 \\
\hline $\begin{array}{l}\text { 4. I consider that the } \\
\text { professor has the proper } \\
\text { preparation to carry out } \\
\text { this activity }\end{array}$ & 4 & 5 & 4.86 & .35 \\
\hline $\begin{array}{l}\text { 5. I would recommend the } \\
\text { tutoring to other students }\end{array}$ & 4 & 5 & 4.82 & .40 \\
\hline $\begin{array}{l}\text { 6. In general I am satis- } \\
\text { fied with the tutoring }\end{array}$ & 4 & 5 & 4.77 & .43 \\
\hline \multicolumn{5}{|c|}{ Action-tutoring strategy timing } \\
\hline $\begin{array}{l}\text { 7. The timetable of the } \\
\text { tutoring was adequate }\end{array}$ & 3 & 5 & 4.55 & .60 \\
\hline $\begin{array}{l}\text { 8. The frequency of the } \\
\text { tutoring was adequate }\end{array}$ & 3 & 5 & 4.64 & .58 \\
\hline $\begin{array}{l}\text { 9. The number of tutoring } \\
\text { sessions was adequate }\end{array}$ & 3 & 5 & 4.50 & .67 \\
\hline \multicolumn{5}{|c|}{ Improvements perceived by the students } \\
\hline $\begin{array}{l}\text { 10. I have improved the } \\
\text { use of my time }\end{array}$ & 3 & 5 & 4.64 & .58 \\
\hline $\begin{array}{l}\text { 11. I have improved my } \\
\text { organization related to my } \\
\text { studies }\end{array}$ & 3 & 5 & 4.36 & .66 \\
\hline $\begin{array}{l}\text { 12. It has helped me } \\
\text { to better choose my } \\
\text { objectives regarding my } \\
\text { opportunities }\end{array}$ & 4 & 5 & 4.68 & .48 \\
\hline $\begin{array}{l}\text { 13. I have learnt study } \\
\text { skills }\end{array}$ & 2 & 5 & 4.05 & .95 \\
\hline $\begin{array}{l}\text { 14. It has helped me to } \\
\text { reflect on my academic } \\
\text { activity }\end{array}$ & 3 & 5 & 4.64 & .58 \\
\hline $\begin{array}{l}\text { 15. I have been able to } \\
\text { analyze the aspects in } \\
\text { which I must improve }\end{array}$ & 3 & 5 & 4.64 & .66 \\
\hline
\end{tabular}

In the open answers 12 out of the 22 students $(55.4 \%)$ made comments. In 11 cases they were positive: six referred to "help they have received from the tutors", five concerned the "interest of professors for their tutored students", but one criticized the frequency of tutoring ( "S5: I wish there were more meetings").

Most students appreciated the help they received from tutors to overcome educational and emotional difficulties, to focus better on study techniques, or to take advantage of and use the tutoring resource more. One student felt that tutoring could also help the professors to have a better understanding of their students:

S8: I think the emotional capacity to cope with problems is what I have developed most. Thanks for helping me to focus better on my studies.

S6: The tutoring seems an excellent idea to orientate the student towards the study of the course and a way for professors to know students better: their concerns, problems, etc.

S7: I like being asked about my situation and to know that they worry.

Other students, however, positively related to the interest of professors to their students tutored:

S1: This is the first time a professor is so aware of my studies.

S2: I never thought that professors would bother to help students with failed subjects. Congratulations.

S20: The tutor has been overseeing me throughout the subject. Thank you.

\section{DISCUSSION}

Previous authors state that there is an emergence of designing, implementing and evaluation of tutoring programs for university students. So the main strength of our study is that the effectiveness of an original tutoring program has been evaluated using a longitudinal and randomized experimental design (Crisp \& Cruz 2009, Meinel et al., 2011).

In addition, we can say that we have validated our main hypothesis of study given that the tutoring program has enabled the EG students to pass $69 \%$ of failed subjects, compared to $37.5 \%$ in the $\mathrm{CG}$, thus improving academic performance in the EG which demonstrates its effectiveness (DeLapp et al., 2008; Jeffreys, 2001; Salinitri, 2005).

On the other hand, we validated our second hypothesis, given that, using reliable instruments, we found benefits of the tutoring program in academic skills and strategies. In fact, EG with respect to $\mathrm{CG}$ showed a high magnitude of improvements in information acquisition about subjects, comprehension of the information provided, and the strategies to improve academic performance (Crisp \& Cruz, 2009; Fernández et al., 2011).

Women showed greater progress than men in the information about subjects and comprehension of the information provided. However, men showed greater progress than women in the acquisition of strategies to improve academic performance. In this respect, future studies should be carried out to know if any possible gender difference in teaching-learning process should be taken into account when developing tutoring strategies.

Following student academic skills and strategies, we found that the greatest difficulties presented at baseline were related to attendance to subject professor tutoring to clear up doubts, examinations with multiple choice questions (which are used by most 
professors at the faculty) and those related to inadequate database management. Particularly striking is the lack of time spent studying and planning it, and the lack of class attendance. On the other hand, although having read the subject syllabus was not one of the worst rated items initially, the importance given by the tutors to this activity could have influenced the high score given in the posttest to the items "I have read the subject syllabus" and "I understand the subject syllabus" in the EG.

A decrease in the standard deviations was observed in all posttest scores in the EG, unlike the CG that maintained the same variability as in the pretest, which reflects greater uniformity in the opinions of EG students after the intervention. This could be related to the adequacy of the program, as the tutors' participation in prior planning and periodic follow-up meetings allowed a uniform application of the same (Guerra-Martín, 2015; Theobald \& Mitchell, 2002; Zabalza, 2011).

Another objective of the study was to determine the assessment made by students about the tutoring program, which has been very positive, highlighting its relevance and its effectiveness, although they would have wanted to improve the focus on study skills. Among the students' perceptions, tutor's help towards the student and the interest shown by professors were highlighted (Jeffreys, 2001; Salinitri, 2005), as opposed to the results obtained by Lee, Anzay and Langlotz (2006), where one of the students' complaints was the lack of availability of the tutor.

Moreover, most of the students valued the professors' interest and the support provided to them, not only academically, but also emotionally and a student stated the benefit of the program that could help the professors to understand better their students. This situation could reflect the psychosocial benefits of tutoring and goes beyond the traditional model to the reciprocal model of tutoring (Arbizu et al., 2005; Arco-Tirado et al., 2011; Jeffreys, 2001; Jones \& Brown, 2011; Phinney et al., 2011). Diverse authors agree that tutors must create an atmosphere that facilitates learning and offer help against stress conditions, or low self-esteem that could lead to poor learning and academic performance (Evans, Brown, Timmins, \& Nicholl, 2007; Gibbons, Dempster, \& Moutray, 2008; Mete \& Yildirim, 2008).

To sum up, from findings of our study we could consider that the tutoring program means by one-one tutoring have had positive influences on the students' learning process, and completion of students' studies (Arbizu et al., 2005; Guerra-Martín, 2015; Watts, 2011).

Dobinson (2006) stressed the importance of support and care to students to enable them to complete their studies, while considering regular meetings for achieving academic success as critical. In our work, each student received a total of nine formal and regular meetings together with others, which were demanded (informal).

\section{LIMITATIONS}

Firstly, although there was a random selection of students it would have been desirable to control the gender and to pair the two groups based on this variable. However, given that nursing studies enroll mainly women this was not possible, so to check for this possible bias, the analysis of results has been performed by gender. Secondly, as although the questionnaire was self-administered, it was applied during the tutoring so the research skills of the tutors could have an effect on the participant' responses. However, we think that the interest of professor collaborators in knowing the real effect of the program has been able to reduce this bias and increase the validity of the study. Thirdly, althou- gh we conducted several team meetings in order to follow-up the program implementation and evaluation, it could be interesting to design a contact $\log$ in order to record tutoring characteristics such as the meeting length. In this way, we could correlate the tutoring time with program effectiveness (Campbell \& Campbell, 1997; Crisp \& Cruz, 2009). Fourth, our sample could be too small to justify the generalization of the conclusions, and it would be appropriate to extend its size in subsequent studies. In the future, more systematic and comprehensive variables should be controlled, since the results obtained could depend on possible factors (motivation, family support, enrichment classes, etc.), which may influence passing a subject and not only in the implementation of the program. Finally, although we found differences by gender it is not possible to draw conclusions based on this variable with the analysis of the data presented.

\section{CONCLUSIONS}

The relevance of this work is in reinforcing tutoring as a fundamental strategy to achieve academic success that is related to quality and excellence within the context of higher education. This presents tutoring as a useful tool for students and professors to improve the students' academic performance in failed subjects. The strategy based on the one-to-one academic tutoring model that is focused on the relationship between tutor and tutee in which the expert professor as coach/assessor of the student has been shown to be effective. In addition, students have positively assessed the tutoring program, by emphasizing the importance of tutors.

Furthermore, the development of a questionnaire for assessment of needs has been useful in the development of this program, to determine the student's training needs and to monitor progress throughout the tutoring.

As nursing students often encounter multiple difficulties while studying their academic career, which can affect performance and involve dropout, this study provides evidence of a program that can help them in the learning process, in their study progress and to pass the outstanding subjects, thus contributing to this important line of research.

\section{ACKNOWLEDGEMENTS}

Funding: This research was supported by a grant from the University of Seville (Spain), project code: 058/A6-2009.

\section{REFERENCES}

Alonso, M. A., Castaño, G., Calles, \& A. M. (2010). Assessment of the efficacy of a peer mentoring program in a university Setting. The Spanish Journal of Psychology, 13, 685-696. doi:10.1017/S1138741600002353

Arbizu, F., Lobato, C., \& del Castillo, L. (2005). Some models for university tutorials. Journal of Psychodidactics, 10, 7-22.

Arco-Tirado, J. L., Fernández-Martín, F. D., \& Fernández-Balboa, J. M. (2011). The impact of a peer-tutoring program on quality standards in higher education. Higher Education, 62, 773-788. doi:10.1007/s10734-011-9419-x

Braine, M. E., \& Parnell, J. (2011). Exploring student's perceptions and experience of personal tutors. Nurse Education Today, 31, 904-910. doi:10.1016/j. nedt.2011.01.005

Campbell, T., \& Campbell, D. (1997). Faculty/student mentoring program: Effects on academic performance and retention. Research in Higher Education, 38(6), 727-742. doi:10.1023/A:1024911904627

Cooke, R., Barkham, K., Audin, K., Bradley, M., \& Davy, J. (2004). How social class differences affect students' experience of university. Journal of Further and Higher Education, 28(4), 407-421. doi:10.1080/0309877042000298894

Crisp, G., \& Cruz, I. (2009). Mentoring College Students: A Critical Review of the Literature Between 1990 and 2007. Research in Higher Education, 50, 525-545. doi:10.1007/s11162-009-9130-2 
Crosier, D., Horvath, A., Kerpanova, V., Kocanova, D., Parveva, T., Rauhvargers, A. (2012). The European Higher Education Area in 2012: Bologna Process Implementation Report (Report). Brussels: Eurydice. Education, Audiovisual and Culture Executive Agency, European Comission. Retrieved from http://bookshop. europa.eu/en/the-european-higher-education-area-in-2012-pbEC3012534/?CatalogCategoryID $=$ QN4KABste0YAAAEjFZEY4e $5 \mathrm{~L}$

DeLapp, T., Hautman, M. A., \& Anderson, M. S. (2008). Recruitment and retention of Alaska Natives into Nursing (RRANN). Journal of Nursing Education, 47(7), 293-297. doi:10.3928/01484834-20080701-06

Dobinson, A. (2006). Personal tutor encounters: understanding the experience. Nursing Standard, 20(50), 35-42. doi:10.7748/ns.20.50.35.s50

Dorsey, L. E., \& Baker, C. M. (2004). Mentoring Undergraduate Nursery Students. Nurse Educator, 29(6), 260-265. doi:10.1097/00006223-200411000-00013

Evans, W., Brown, G., Timmins, F., \& Nicholl, H. (2007). An exploratory study identifying the program related stressors amongst qualified nurses completing part-time degree courses. Nurse Education Today, 27, 731-738. doi:10.1016/j. nedt.2006.10.015

Fernández, F. D., Arco, J. L., López, S., \& Heilborn, V. A. (2011). Prevención del fracaso académico universitario mediante tutoría entre iguales [University academic failure prevention by peer tutoring]. Revista Latinoamericana de Psicología, 43(1), 59-71.

Field, A. P., \& Babbie, E. R. (2011). Discovering statistics using SPSS: (and sex and drugs and rock'n'roll). London: SAGE.

Fowler, J., \& Norrie, P. (2009). Development of an attrition risk prediction tool. The British Journal of Nursing, 18(19), 1194-1200. doi:10.12968/ bjon.2009.18.19.44831

Gibbons, C., Dempster, M., \& Moutray, M. (2008). Stress and eustress in nursing students. Journal of Advanced Nursing, 61, 282-290. doi:10.1111/j.13652648.2007.04497.x

Glossop, C. (2002). Student nurse attrition: use of an exit interview procedure to determine students' leaving reasons. Nurse Education Today, 22(5), 375-386. doi:10.1054/nedt.2001.0724

Gómez-Collado, M. E. (2012). The perception of students on the Academic Tutelage. Convergencia. Revista de Ciencias Sociales, 58, 209-233.

Guerra-Martín, M. D. (2014). Tutoring as a way of achieving employability for nursing students at the University of Seville. Procedia-Social and Behavioral Sciences, 139, 479-486. doi:10.1016/j.sbspro.2014.08.049

Guerra-Martín, M. D. (2015). Características de las tutorías realizadas por el profesorado de los estudios de Enfermería de la Universidad de Sevilla. Sevilla: Punto Rojo Libros.

Guerra-Martín, M. D., Lima-Serrano, M., \& Lima-Rodríguez, J. S. (2016). Opinions of nursing professors and students regarding the content of the mentoring program. Enfermería Global, 15(3), 188-211.

Hauer, K. E., Teherani, A., Dechet, A., Aagaard, E. M. (2005). Medical students' perception of mentoring: a focus group analysis. Medical Teacher, 27(8), 732-739. doi: $10.1080 / 01421590500271316$

Hernández, Y., Martínez, J. C., \& Carranza, C. I. (2013). Institutional Tutoring Program: a strategy for raising standards of achievement in an educational institution. Acta Universitaria, 23(1), 31- 36

Hryciw, D. H., Tangalakis, K., Supple, B., \& Best, G. (2013). Evaluation of a peer mentoring program for a mature cohort of first-year undergraduate paramedic students. The American Physiological Society, 37, 80-84. doi:10.1152/advan.00129.2012

Jeffreys, M. R. (2001). Evaluating enrichment program study groups: Academic outcomes, psychological outcomes, and variables influencing retention. Nurse Educator, 26(3), 142-149. doi:10.1097/00006223-200105000-00017

Jones, R., \& Brown, D. (2011). The Mentoring Relationship as a Complex Adaptive System: Finding a Model for Our Experience. Mentoring \& Tutoring: Partnership in Learning, 19(4), 401-418. doi:10.1080/13611267.2011.622077

Lee, J. M., Anzay, Y., \& Langlotz, C. P. (2006). Mentoring the Mentors: Aligning Mentor and Mentee Expectations. Academic Radiology, 13(5), 556-561. doi:10.1016/j.acra.2006.01.050

Lemus, L. A., Torres, F. S., Serrano, M., \& Gúzman, G. (2015). La tutoría: eje fundamental para mejorar el rendimiento académico de alumnos de nivel superior. Innovación Educativa, 15(67), 89-110

Lima-Rodríguez, J. S., Lima-Serrano, M., Jiménez-Picón, N., Domínguez-Sánchez, I. (2013). Content Validity of Family Self-Perception of Family Health Status Scale. Revista Latinoamericana de Enfermagen, 21(2), 595-603.

Meinel, F. G., Dimitriadis, K., Von der Borch, P., Störmann, S., Niedermaier, S., \& Fischer, M. R. (2011). More mentoring needed? A cross-sectional study of mentoring programs for medical students in Germany. BMC Medical Education, 11, 68. doi:10.1186/1472-6920-11-68

Mete, S., \& Yildirim, H. (2008). Nursing students' expectations from tutors in PBL and effects of tutors' behaviour on nursing students. Nurse Education Today, 28(4), 434-442. doi:10.1016/j.nedt.2007.07.008

Miller, A. (2002). Mentoring students \& young people: A handbook of effective practice. London: Kogan Page. doi:10.4324/9780203417188
Ministry of Education and Science (2014). Objetivos Educativos Europeos y Españoles. Estrategia Educación y Formación 2020. Informe español 2014 (Report). Madrid: Subdirección General de Documentación y Publicaciones. Secretaría General Técnica. Retrieved from

http://www.mecd.gob.es/dctm/inee/internacional/et2020informe-espanol-2014. pdf?documentId $=0901 \mathrm{e} 72 \mathrm{~b} 81 \mathrm{c} 42 \mathrm{cf} 3$

Ministry of Education, Culture and Sport (2015). Sistema estatal de indicadores de la educación. Edición 2015 (Report). Madrid: Secretaría General Técnica. Instituto Nacional de Evaluación Educativa. Retrieved from http://www.mecd gob.es/servicios-al-ciudadano-mecd/dms/mecd/servicios-al-ciudadano-mecd/ estadisticas/educacion/indicadores-publicaciones-sintesis/sistema-estatal-indicadores/SEIE_2015.pdf

Paglis, L. L., Green, S. G., \& Bauer, T. N. (2006). Does advisor mentoring add value? A longitudinal study of mentoring and doctoral student outcomes. Research in Higher Education, 47(4), 451-476. doi:10.1007/s11162-005-9003-2

Perandones, T. M. \& Lledó, A. (2009). La función del profesorado universitario como tutor: Experiencias en el programa de Acción Tutorial en la Universidad de Alicante [Role of university professor as tutor: experience in the action-tutoring program at the University of Alicante]. In R. Roig (Ed.), Investigar desde un contexto educativo innovador (pp. 359-368). Alcoy: Marfil.

Peterson, V., Bryer, J., \& Nikolaidou, M. (2013). Self-esteem and self-efficacy as predictors of attrition in associate degree nursing students. Journal of Nursing Education, 52(6), 351-354. doi:10.3928/01484834-20130520-01

Phinney, J. F., Torres, C. M., Padilla, D. M., \& Kim, C. (2011). Processes and Outcomes of a Mentoring Program for Latino College Freshmen. Journal of Social Issues, 67(3), 599-621. doi:10.1111/j.1540-4560.2011.01716.x

Pope, C., Ziebland, S., \& Mays, N. (2000). Qualitative research in health care: Analysing qualitative data. British Medical Journal, 320, 114-116. doi:10.1136/ bmj.320.7227.114

Pryjmachuk, S., Easton, K., \& Littlewood, A. (2009). Nurse education: Factors associated with attrition. Journal of Advanced Nursing, 65, 149-160. doi:10.1111/ j.1365-2648.2008.04852.x

Rhodos, S., \& Jinks, A. (2005). Personal tutor's view of their role with pre-registration nursing students: An exploratory study. Nurse Education Today, 25, 390397. doi:10.1016/j.nedt.2005.03.008

Salinitri, G. (2005). The Effects of Formal Mentoring on the Retention Rates for First-Year, Low Achieving Students. Canadian Journal of Education, 28(4), 853-873. doi: $10.2307 / 4126458$

Scott, E. S. (2005). Peer-to-peer mentoring: teaching collegiality. Nurse Educator, 30(2), 52-56. doi:10.1097/00006223-200503000-00004

Theobald, K., \& Mitchell, M. (2002). Mentoring: Improving transition to practice. Australian Journal of Advanced Nursing, 20(1), 27-33.

Urwin, S., Stanley, R., Jones, M., Gallagher, A., Wainwright, R., \& Perkins, A. (2010). Understanding student nurse attrition: learning from the literature. Nurse Education Today, 30(2), 202-207. doi:10.1016/j.nedt.2009.07.014

Valverde, A., García, E., \& Romero, S. (2003). La función tutorial en la Universidad de Sevilla. La mentoría como respuesta: el proyecto S.I.M.U.S. In P. R. Álvarez \& H. Jiménez (Eds.), Tutoría Universitaria (pp. 269-284). La Laguna: University of La Laguna Publish Service.

Velázquez-Sagahón, F-J, \& Rodríguez de la Osa, H-E. (2014). Design and implementation of subject tutoring in the degree program in administrative information systems of the Guanajuato University. Revista Iberoamericana de Educación Superior, 5(14), 41-54. doi:10.1016/S2007-2872(14)70299-9

Watts, T. E. (2011). Supporting undergraduate nursing students through structured personal tutoring: some reflections. Nurse Education Today, 31, 214-218. doi:10.1016/j.nedt.2010.06.005

Wild, L., \& Ebbers, L. (2002). Rethinking student retention in community colleges. Community College Journal of Research and Practice, 26(6), 503-519. doi:10.1080/2776770290041864

Zabalza, M. A. (2011). Competencias docentes del profesorado universitario: Calidad y desarrollo profesional. Madrid: Narcea.

How to cite this article: Guerra, J., Lima, M., \& Lima, J. S. (2017).

Effectiveness of Tutoring to Improve Academic Performance in Nursing Students at the University of Seville. Journal of New Approaches in Educational Research, 6(2), 93-102. doi: 10.7821/naer.2017.7.201 